\title{
Muriel Casals, professora d'economia per a futurs geògrafs
}

Muriel Casals va morir a Barcelona el 14 de febrer de 2016, després de patir un accident de trànsit. Havia nascut el 6 d'abril de 1945 a Avinyó, França.

Què es pot dir de Muriel Casals que no s'hagi dit ja? La seva sobtada mort ha propiciat molts escrits i discursos elogiosos sobre la seva persona, la majoria vinculats a la seva faceta cívica i política: la dona forta de la revolució dels somriures. Aquí voldria recordar la seva altra cara, la d'economista i professora d'universitat.

Aquesta faceta va ser la que va ocupar la major part de la vida pública de Muriel Casals. En efecte, llicenciada en Economia per la Universitat de Barcelona, el curs 1969-1970 es va incorporar com a professora a la Facultat de Ciències Econòmiques i Empresarials de la nova Universitat Autònoma de Barcelona (segona època, després de l'anterior a la Guerra Civil), on es va doctorar el 1981. A la UAB no es va limitar a ser-ne professora. Va ocupar càrrecs, entre d'altres el de vicerectora de Relacions Internacionals i de Cooperació (2002-2005). Al mateix temps, era una persona políticament compromesa i activa en altres tasques, i era coneguda com a articulista de diaris i revistes tan significats com el setmanari El Temps.

Recordo molt bé el moment de l'inici del seu salt a una activitat cívica més pública i marcada. Un dia ens vam creuar a la plaça Cívica de la UAB; ella, camí de la seva facultat, i jo, camí del l'estació dels FGC, que ja me'n tornava cap a Barcelona. Em va dir: «Saps què? M'han proposat presentar-me al càrrec de presidenta d'Òmnium Cultural». Dubtava. Jo la vaig animar força i finalment vaig saber que la seva decisió va ser a favor d'acceptar. Ja amb el càrrec, assumit el març de 2010, va continuar amb la docència una temporada, i un dia, ja molt més endavant, en una altra trobada, em va dir que finalment sí, que deixava la docència i agafava la jubilació. De fet, la dedicació a Òmnium havia adquirit una intensitat tal que feia difícil compaginar-ho amb una altra feina tan absorbent com és la docència ben entesa.

En els inicis de la Universitat Autònoma de Barcelona, primer a Sant Cugat i de seguida als nous edificis de ciment de Bellaterra, el geògraf Enric Lluch va muntar el Departament de Geografia. Partidari de la interdisciplinarietat, en el nou departament hi havia economistes, sociòlegs i cartògrafs, a part dels geògrafs. Alguns d'integrats en el mateix departament i d'altres que venien a 
fer classes des d'altres departaments. La Muriel Casals es va encarregar molts anys de les classes d'economia. L'entesa va ser total. Era companya de docència i era alhora amiga de molts de nosaltres, els professors del Departament. També es va implicar a fons en la revista del Departament, Documents d'Anàlisi Geogràfica, de la qual va ser membre del Consell Assessor des de l'any 2006. I, quan se li demanava, participava en cursos de doctorat sense fer-se pregar. D'altra banda, a la Facultat de Ciències Econòmiques a la qual pertanyia, sempre es va voler fer càrrec de les assignatures de primer curs de la carrera, les assignatures amb més estudiants i, en certa manera, les menys valorades i les que no proporcionen prestigi als docents que les assumeixen. És clar que ella, veterana i respectada professora, hauria pogut sol-licitar altres encàrrecs. Però no, deia que ja li anava bé, i ho compaginava amb les classes als estudiants de Geografia. Tot un luxe per a ells i per a nosaltres.

Vull acabar amb un text del llibre que ha escrit el seu amic Quim Torra, Muriel Casals i la revolució dels somriures (Pòrtic, 2016, p. 31). Hi explica que la Fundació Jaume Bofill li va preguntar el 2014 quines coses havia après dels seus anys de professora. La seva resposta: «Primer, la paciència, no tenir pressa; segon, la humilitat, els professors no ho sabem tot, i tercer, la classe magistral és útil».

Àngels Pascual de Sans, professora jubilada del Departament de Geografia de la UAB. Barcelona, desembre de 2016. 